\title{
Consumption, Income Distribution, and State Ownership in the People's Republic of China
}

\section{By}

\section{Yuqing Xing}

Oct 2010
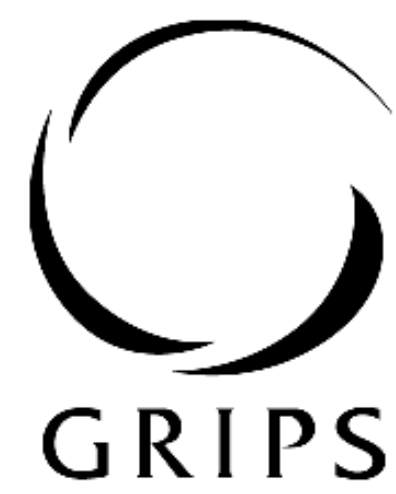

National Graduate institute FOR POLICY STUDIES

National Graduate Institute for Policy Studies

7-22-1 Roppongi, Minato-ku,

Tokyo, Japan 106-8677 


\title{
Consumption, Income Distribution, and State Ownership in the People's Republic of China
}

\section{Yuqing Xing}

\section{National Graduate Institute for Policy Studies}

\begin{abstract}
It is income rather than the peculiar saving behavior of Chinese households that constrains consumption in the People's Republic of China. The low share of consumption in gross domestic product (GDP) is consistent with the reduced share of GDP of wage earnings - a major source of household income. Corporate savings, which accounted for $23 \%$ of national income in 2007 , contributed most to the significant increase in the gross national saving rate. The surging corporate savings was mainly due to the bias of income distribution toward capital. The profits of state-owned enterprises (SOEs) made with monopolistic power and government support comprises a substantial part of corporate savings. A series of enterprise reforms have made SOEs leaner and bigger, and transformed a handful central SOEs into monopolies in highly profitable industries. Retained profits by SOEs only benefit managers and employees in these firms, not the general public who are their true owners. The empirical analysis indicates that high levels of compensation by SOEs contributed to rising inter-industry income disparity. To boost domestic demand, it is essential that the government address the bias in distribution between SOEs and households. Collecting dividends from SOEs to fund social welfare systems or direct income transfers to low-income families will reduce the gross national saving rate, boost consumption, and more importantly, mitigate social inequality.
\end{abstract}

Key Words: China, Saving, Income Disparity and State Ownership

\footnotetext{
"National Graduate Institute for Policy Studies, 7-22-1 Roppongi, Minato-ku, Tokyo, 106-8677, Japan; yuqing xing@grips.ac.jp. Comments from the participants of the ADBI Annual Conference and the Brown Bag Seminar at ADBI are highly appreciated. The author is grateful for the financial support of ADBI.
} 


\section{Introduction}

Global imbalances have been frequently cited as a structural problem causing the current financial crisis. With a gross national saving rate of more than $50 \%$ and more than US\$2 trillion in foreign exchange reserves, the People's Republic of China (PRC) unambiguously belongs to the camp with excess savings, and is expected to reduce its savings in order to help resolve the imbalance. Chinese consumers are expected to open their wallets, transform their wealth in savings accounts into consumption, and offset the global demand shortage left by distressed American consumers. Encouraging greater domestic consumption would not only contribute to the recovery of the world economy, but would also mitigate the over dependence of the Chinese economy on external demand and facilitate its transition to balanced growth.

To achieve this objective, government policy initiatives are necessary, at least in the short run. However, whether the objective could eventually be accomplished depends on the capacity and consumption propensity of Chinese households, not on the government and enterprises of the PRC. Therefore, how to encourage Chinese consumers to spend more and save less seems to be a challenging policy issue. A plethora of studies are available attempting to explain the low consumption-high savings puzzle of Chinese households. Precautionary motives, due to the rising private burden of health, education, and housing costs are argued to be one of the major reasons the Chinese save so much (Chamon and Prasad 2008; Meng 2003). Using the life-cycle theory, Modigliani and Cao (2004) attributed the PRC's high saving rate to significant income growth and demographic changes. The rigid one-child policy implemented since the late-1970s resulted in substantial demographic changes. As a consequence, the PRC began the transition to an aging society at an early stage not compatible with the level of its economic development. Workers have strong incentives to save more to prepare for retirement. The pension reform associated with the reform of state-owned enterprises (SOEs) further enhanced the saving propensities of the Chinese (Feng, He, and Sato 2009).

The rising propensity to save is in fact just one factor contributing to the decline in the share of consumption in the PRC's gross domestic product (GDP). It explains a very small portion of the decline since the 1990s (Aziz and Cui 2007). The fundamental factor, household income-which ultimately determines household consumption-has been given less attention in academic analyses and debates on the PRC's low consumption-high savings puzzle. Without scrutinizing the dynamic changes in household income relative to national income, it is difficult to infer whether consumption's low share of GDP was due to more conservative consumption behavior-i.e., saving more-or simply a result of the decrease in the share of GDP 
In addition, as a transitional economy, the structure of national savings in the PRC differs from that in traditional market economies. In particular, corporate savings, of which SOEs are the main contributors, exceeded $20 \%$ of national income and emerged as the major source of the PRC's savings glut. Identifying who are the savers is crucial for making effective policies to encourage converting savings into consumption.

In this paper, we examine the PRC's high savings myth at both macro and micro levels, and analyze the relationship between low consumption and income disparities. Also examined is the disparity between capital and labor, and between state and non-state sectors. At the macro level, we study the composition of PRC national savings, investigate the relationship between labor's income and the share of consumption in GDP, and compare household saving behavior in the PRC with that in Japan. At the micro level, we review the advance of SOEs and state banks from the verge of bankruptcy to profitability and monopoly. We argue that profits in the state-owned sector contributed substantially to rising corporate savings and benefited mainly managers and employees of SOEs, not their real owners-the general public, thus widening income disparity between state and non-state sectors. The empirical results based on regression analysis show that state ownership is one of the significant factors driving inter-sector income disparity. Our analysis suggests that reducing corporate savings should be given high priority for boosting domestic consumption. Collecting dividends from SOEs for either direct income transfers or for funding social safety nets would not only boost consumption, but more importantly, enhance social equity.

\section{Saving, Consumption, and Income Disparity at the Macro Level}

\subsection{The Role of Corporate Savings}

In 2008 , the national saving rate in the PRC rose to $51.4 \%, 13.7$ percentage points higher than in 2000. Compared with past records, the gross national rate surged substantially. For the world as a whole, the saving rate has been relatively stable and has ranged from $21 \%$ to $27 \%$ since 1970 (Wiemer 2009). It is fair to say that the PRC's gross national saving rate is extraordinarily high and definitely beyond the international norm.

In a typical economy, national savings is composed of household savings, corporate savings, and government savings. In spite of 3 decades of economic reform, the structure of the PRC economy differs substantially from market economies. The PRC remains a transitional economy. Imperfect competition, various government regulations and interventions, and the dominance of SOEs in many profitable industries often favor the government and SOEs in the allocation of national income. Corporate and government savings play a much more important role in the PRC economy than in 
traditional market economies. Kuijis (2005) argues that most of the difference in national savings between the PRC and other countries is due to corporate savings.

Understanding who does the saving is crucial when proposing measures aimed at reducing savings and expanding consumption. In order to identify major factors driving the increases in the national saving rate, it is imperative to scrutinize each component of savings. Simply focusing on household savings would not yield a full picture of savings dynamics, nor would it help find effective means of reducing the saving rate. The trends and dynamic changes in the composition of national savings in the PRC from 1992 to 2007 are shown in Figure 1, based on data presented in a speech in 2009 by Zhou Xiao Chuan of the People's Bank of China. During the period shown, household savings first followed a declining trend-accounting for $20.3 \%$ of the national income in 1992 , then gradually decreasing to $17.0 \%$ by 2001 . Household savings then started to recover and reached $20.0 \%$ of national income in 2007 , almost the same level as in 1992. In other words, household savings changed very little during the period.

Figure 1: Distribution of Saving Among Corporations, Households, and the PRC Government (\% of national disposable income)

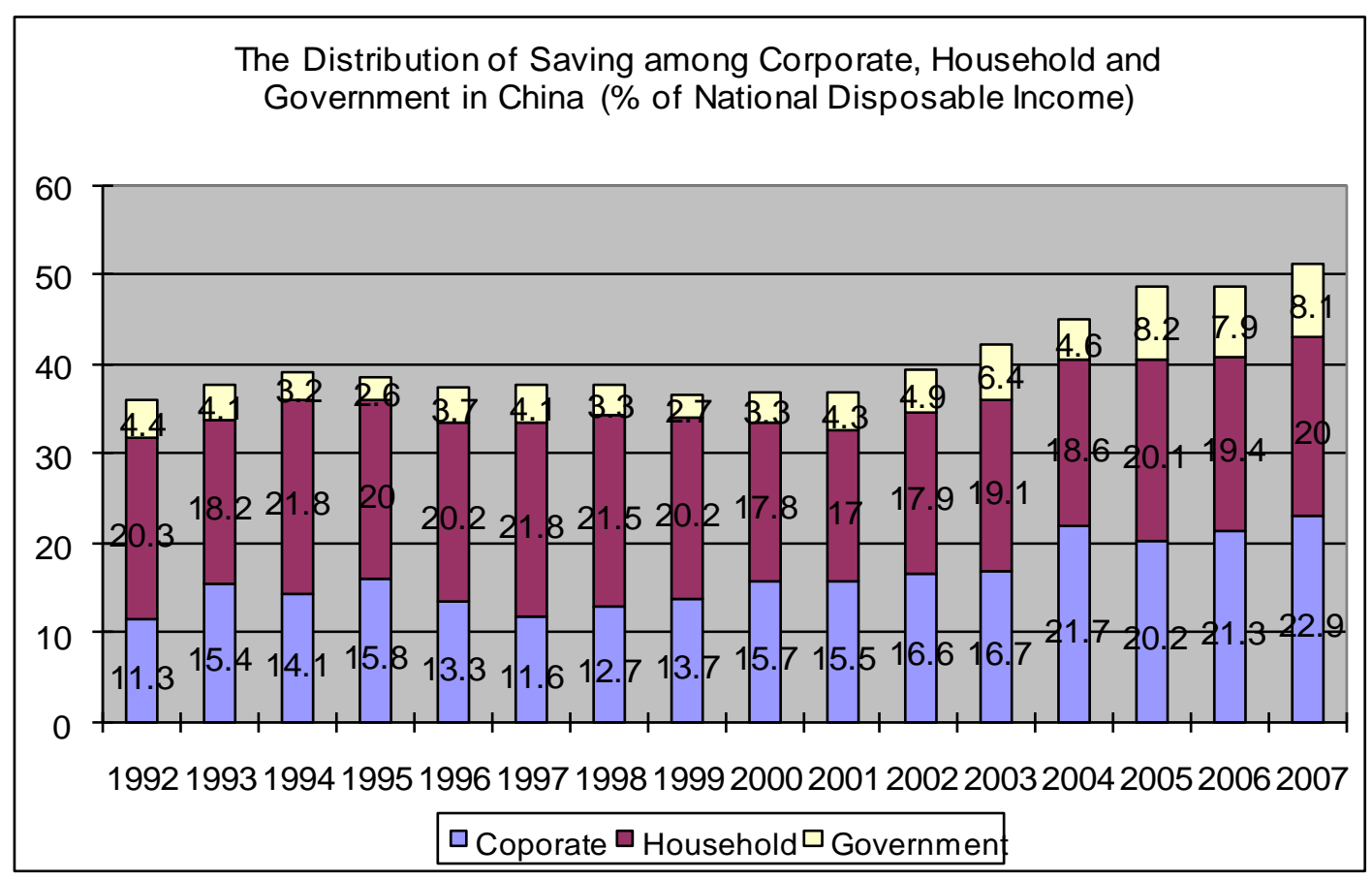

Source: Zhou (2009).

In contrast, both government and corporate savings as a share of national income grew rapidly. In 1992, corporate savings accounted for $11.3 \%$ of national income 
and government savings for $4.4 \%$. Corporate savings grew almost steadily after 1997 , rising to $22.9 \%$ in 2007 , more than double the level of 1992 . Government savings fluctuated around $4.0 \%$ before 2002 , then climbed rapidly to $8.1 \%$ of national income in 2007. The structural change in national savings from 1992 to 2007 indicates that the significant increase in corporate savings contributed most to the rise in the gross national saving rate. Household savings' share in national income actually dropped 0.3 percentage points from 1992 to 2007, and thus could not make any positive contribution to increases in the gross national saving rate. In other words, of the three components of national savings, household savings made the smallest contribution to the high national saving rate. Analysis of the composition of national savings based on flow-of-funds data ${ }^{1}$ in the country's national accounts also suggests that corporate savings became more significant than household savings in the last decade (Tyers and Lu 2009). Hence, in order to promote domestic consumption, policy prescriptions simply focused on household savings would actually miss the real target and would not be effective.

Imperfections in the labor market—where excess supply remains-are among the reasons PRC enterprises have continuously generated a rising share of national savings in recent years. An almost unlimited supply of labor from rural areas undermines the bargaining power of workers and constrains wage increases. Empirical studies show that wages in the PRC grew much slower than workers' productivity. Workers were actually paid about $25 \%$ to $30 \%$ of marginal labor revenue (Cai, Wang, and Qu 2009). The PRC economy has grown about 10\% annually in the last 3 decades. The declining share of wage income in GDP implies that enterprises have gained relatively more from economic growth compared to workers.

Another critical factor responsible for the rise in corporate savings was a series of SOE reforms, and government policy to retain state control in strategic industries such as mining, petroleum refining, steel, and telecommunication. State control of these industries serves as a means of maintaining socialist characteristics within a market economy-the so-called "socialist market economy." The enterprise reforms implemented since late 1990 have significantly reduced the number of SOEs and eliminated millions of redundant workers, thus converting surviving SOEs into leaner, more competitive, and profitable firms. Moreover, supported by government policies, SOEs have monopolized many industries which are very profitable in an economy that is growing rapidly on the way toward industrialization.

The huge monopolistic rents and retained profits of these enterprises comprise a major source of corporate savings (Lu et al. 2008; Tyers and Lu 2009). In 2007,

\footnotetext{
${ }^{1}$ Financial in-flows and out-flows among all sectors of an economy.
} 
state-owned-and-controlled companies earned net profits of CNY1.62 trillion, equivalent to $6.5 \%$ of the PRC's GDP and $31.8 \%$ of the government's fiscal revenue. A handful of central SOEs (about 140 large firms), which are under the jurisdiction of the central government, accounted for CNY1.1 trillion of net profits, or about $68 \%$ of the record profits of SOEs in 2007 (Ministry of Finance 2008).

\subsection{Comparing Household Saving Behavior in the People's Republic of China and Japan}

In addition to the high national saving rate, the rising household saving rate estimated on the basis of household survey data is also cited as evidence that Chinese consumers save too much. However, a high saving rate was a common phenomenon in the so-called East Asian Miracle. Following the success of Japan and the newly industrialized economies, Hong Kong, China; Republic of Korea; Singapore; and Taipei,China adopted export-led growth strategies at the beginning of their economic reforms. The use of savings from current accounts surpluses to support the investment needed for rapid economic growth was the means of implementing an export-led growth strategy.

Do Chinese households save more than their peers in other east Asian countries? To investigate whether Chinese households are really an outlier in this regard in the international perspective, the household savings path in the PRC from 1990 to 2007 was compared with that in Japan from 1960 to 1977. A rationale for this comparison is that both economies grew rapidly in the periods examined. Along with economic growth, household saving rates in each economy rose sharply. Further, in 1990, the level of economic development the PRC roughly matched that of Japan in 1960. GDP per capita of the PRC at the beginning of the 1990s was about the same level as that in Japan in 1960.

Figure 2 shows the trends of household saving rates in the PRC and Japan. In 1960 , Japan's household saving rate was $14.7 \%$. It grew steadily and reached a peak of $23.1 \%$ in 1975 , then decreased slightly to $21.7 \%$ by 1977 . The trend of household savings in the PRC was similar. In 1990, households there saved about $15.1 \%$ of their disposable income. Their saving propensity gradually increased to $24.3 \%$ in 2005 , almost the same level that Japanese households achieved within the same period of time (15 years). The saving rate in the PRC continued to rise to $27.5 \%$ by 2007 , however. The evolution of household saving rates in the PRC basically followed the path of Japanese households during that country's period of rapid economic growth from 1960 to 1977. Compared with Japan, it is not evident that PRC households are an outlier and save excessively. 
Figure 2: Comparing Household Saving Rates between the PRC and Japan

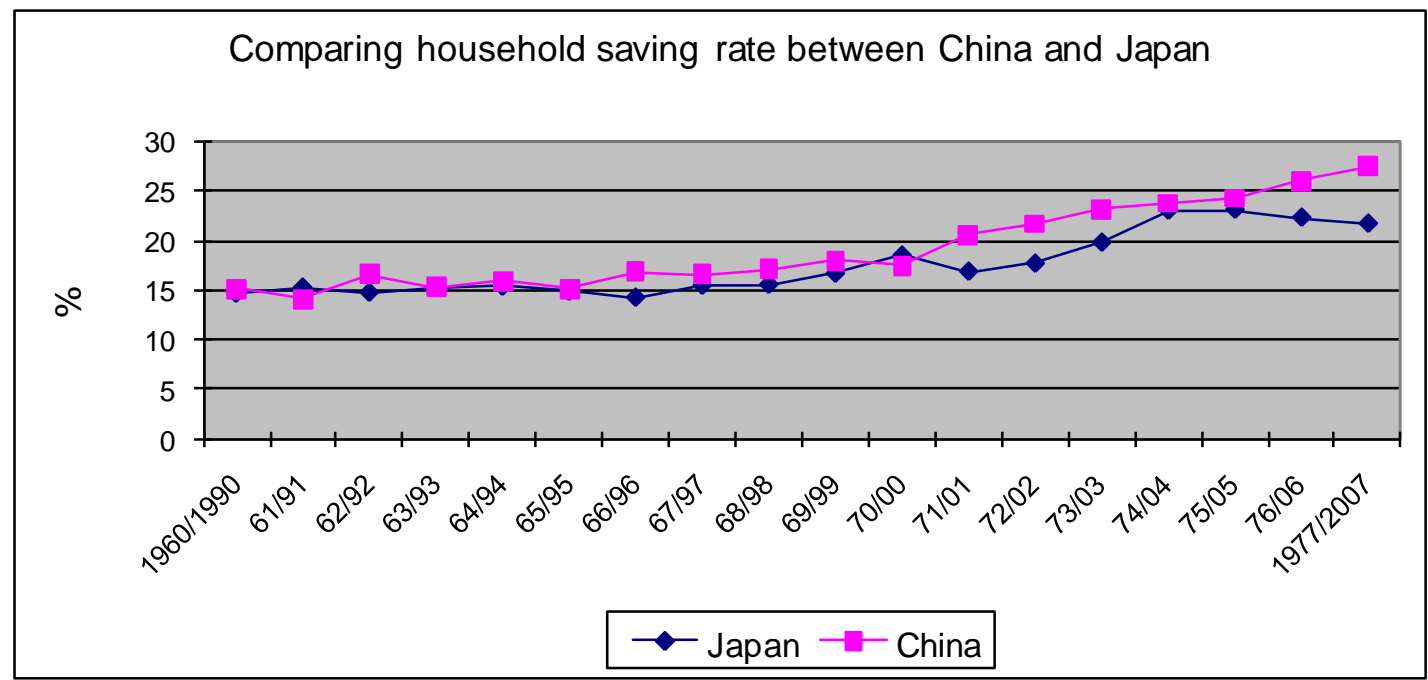

Source: Prasa (2002), Japanese Cabinet Office (2005), China Statistics Yearbook, and Author's calculations.

An obvious difference is that Japan's household saving rate peaked in 1975, while that of the PRC continued to grow after 2005. However, in PRC household surveys, consumers' purchases of houses are classified as investments. The welfare allocation for housing was abolished by the government in 1998. Faced with rising housing prices, mortgage payments have comprised a large portion of monthly expenditures of individual households in urban areas. Monthly mortgage payments are usually considered savings, not consumption. In addition, pitfalls in the survey methodology may underestimate household propensity for consumption. An official of the Chinese Statistics Bureau acknowledged that survey methodology was designed in the 1980s and failed to reflect subsequent structural changes in the economy (Peng 2009). Many consumption expenditures, such as school selection fees and under-the-table payments for visits to doctors in hospitals, are not covered by the survey. Rents for houses are based on house construction cost rather than on market value, thus underestimating household consumption. Given these facts, the 4-percentage-point difference between the peaks of household saving rates in the PRC and Japan may not support the view that Chinese consumers save more than their counterparts in Japan.

\subsection{Low Consumption and the Shrinking Share of Wage Income}

In addition to savings parameters, macroeconomists examine the share of 
household consumption in GDP to evaluate whether private consumption is sufficient. Chinese household consumption as a share of GDP has been decreasing steadily since 1995. It shrank to $35 \%$ of GDP in 2007 , lower than the averages for the world and for high-, middle- and low-income country groups (Xing 2009). Declining consumption seems to be convincing evidence that Chinese households save too much. They should consume more in order to boost domestic demand and alleviate the global imbalance. This reasoning is valid only if the household income as a share of GDP remains constant.

The consumption share is the ratio of household consumption to GDP. If household income as a share of GDP decreases, the consumption share will decrease correspondingly regardless whether saving propensity increases or not. In other words, changes in national income distribution between households and enterprises also affect the share of consumption in GDP. Specifically, for any given consumption propensity, a decrease in the share of household income in national income will lower consumption proportionally. Therefore, in order to explore the low consumption phenomenon and test the hypothesis that conservative saving behavior resulted in low consumption, it is essential to analyze whether income distribution has been constant, and to what extent the decrease in the share of household consumption in GDP was due to shrinking income.

Due to underdeveloped financial markets and the limited availability of investment opportunities, wage income remains a major source of household income in the PRC. The share of wage income in GDP, however, dropped sharply in recent years. It accounted for $53.0 \%$ of GDP in 1995 and exceeded half of GDP before 2002. It dipped to $49.5 \%$ in 2003 , the first time in the last 3 decades that wage income accounted for less than half of national income. Since then, the share of wage income in GDP decreased continuously and in 2007 fell to $39.7 \%$, more than 13 percentage points lower than in 1995.

Without a doubt, the falling share of wage income in GDP contributed to the decline in household consumption, as wage income accounts for $89 \%$ of household income in urban areas. The trends of household income and consumption from 1995 to 2007 are compared in Figure 3. Each is measured as a share of GDP. During the period examined, household consumption dropped about 10 percentage points from $45 \%$ to $35 \%$ of GDP, while household income fell 13 percentage points. Rigorous analysis may be needed to accurately quantify to what extent the decrease in household consumption was due to the shrinking share of household income. The simple comparison, on the other hand, unambiguously suggests that falling income, rather than changes in saving behavior, is a major factor driving down consumption. 
Figure 3: Household Consumption and Labor Shares in GDP

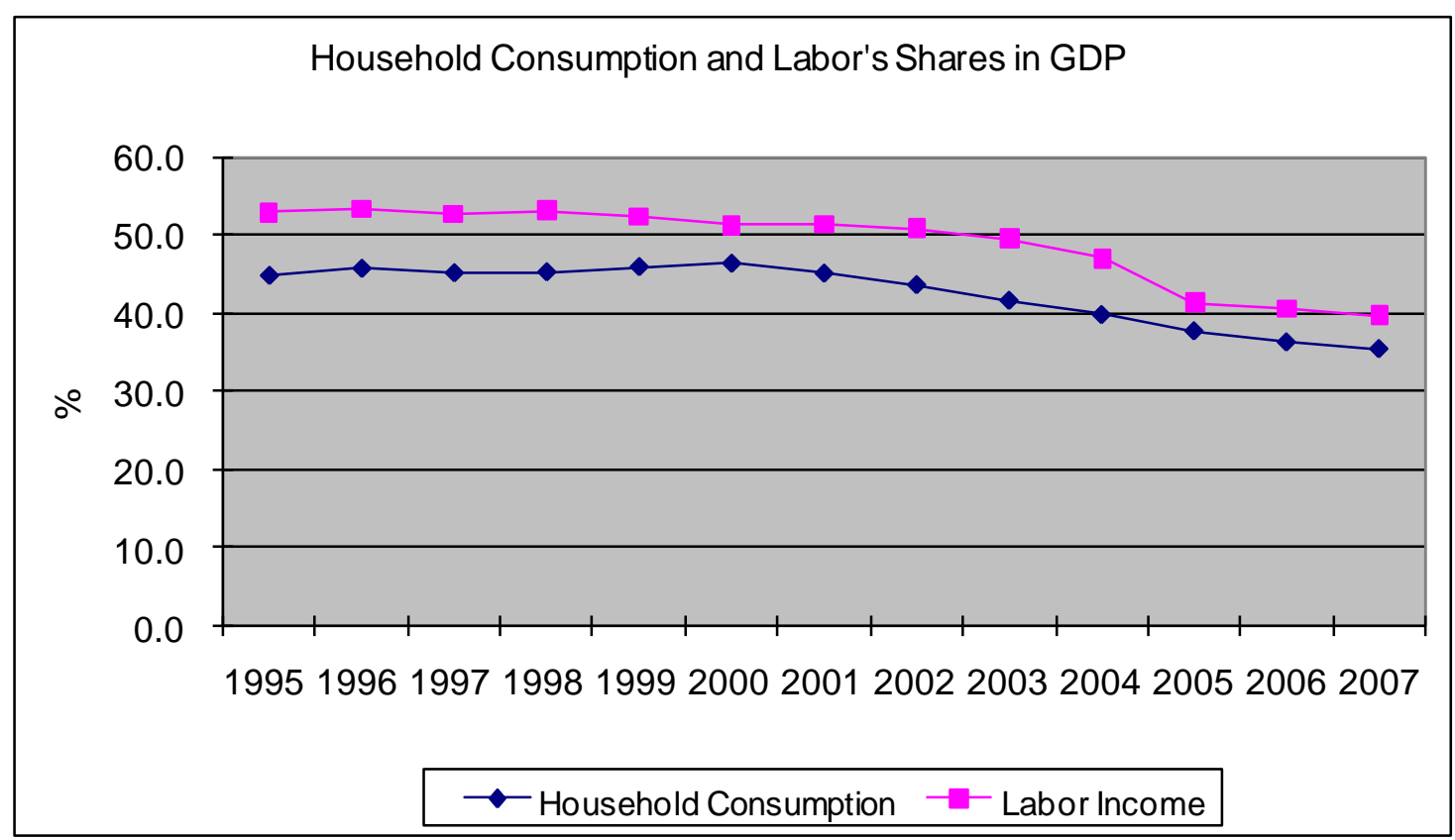

Source: Lu and Gao (2009) and China Statistics Yearbook.

The descriptive analysis of the composition of savings and dynamic changes in the share of household income in GDP suggest that rising corporate savings contributed most to the increase in the PRC's national saving rate. Despite the increase of the household saving rate, at the macro level, household savings as a share of national income was constant, thus contributing little to the growth of the gross national saving rate. Measures aimed at reducing high national savings should focus on the right target: corporate savings.

Economic reforms implemented in the last 3 decades have mainly emphasized efficiency and benefited capital much more than labor. They gave rise to income distribution biased toward enterprises and a decrease in the share of household income. Biased income distribution and the shrinking share of household income constrained the consumption capacity of Chinese households and brought about a continuous decline in consumption as a share of GDP. A few studies pointed out the negative impact of income disparity on aggregate consumption in the PRC (e.g, Wan 2007). Low-income families tend to have a higher consumption propensity than high-income families. Redistributing income from the latter to the former would enhance aggregate consumption. The income distribution problem discussed in this paper, however, differs from the more conventional discussions of income disparity in these studies. The distribution of income between enterprises and households-in particular, between 
SOEs and their owners, the general public-is discussed here, not the distribution between high- and low-income households.

According to the deputy director of the research institute of State-owned Assets Supervision and Administration Commission (SASAC), on average, a Chinese citizen nominally owns CNY13,000 in assets of non-financial SOEs $\left(21^{\text {st }}\right.$ Century Business Herald 2009). Under current policy, ordinary citizens benefit neither directly nor indirectly from this ownership. Shifting savings from SOEs to households would not only stimulate consumption, but more importantly, would enhance social justice; in theory, all SOEs are owned by Chinese citizens.

\section{Reform of State-Owned Enterprises, State Monopoly, and Income Distribution} 3.1 The Transformation of State-Owned Enterprises: from Losses to Profitability and Monopoly

Reforming state-owned enterprises has been one of the major tasks on the agenda of economic reform in the PRC since 1978. A variety of measures and approaches have been tried to restructure inefficient, mismanaged, and unprofitable SOEs. At the early stage of enterprise reform, state ownership was left untouched. Reform policies were guided by questions about how to strengthen the competitiveness, improve the efficiency, and increase the profits of SOEs. Various incentive mechanisms were introduced, such as bonuses and profit retention systems, and managers' autonomy in enterprise operations was expanded. To enhance the vitality of SOEs, tax reform was launched in the mid-1980s, aiming to replace the profit remittance system with a corporate tax system. Starting from 1987, enterprise reform concentrated on restructuring the SOE management mechanism. The primary objective was to strengthen the responsibility of management. Measures adopted included leasing in small SOEs, a contract system in large SOEs, and the shareholding system (Lin, Cai, and Li 2003).

These limited reforms did not solve fundamental problems: corporate governance and ownership that was not clearly defined. Reforming the ownership structure of SOEs and instituting standardized corporate governance began in the early 1990 s. To facilitate corporatization of SOEs, the Company Law was passed in 1993. Under this law, SOEs could be restructured into one of three types of companies: a wholly state-owned company, a limited liability company, or a company owned by shareholders. ${ }^{2}$ Corporatization actually represented the beginning of the privatization process for SOEs.

\footnotetext{
${ }^{2}$ For the definitions, please see Explanatory Notes on Main Statistical Indicators in Chapter 13 of National Bureau of Statistics (2008).
} 
Radical reforms occurred in 1997 after the government formulated a new enterprise reform strategy: "grasping the large and letting the small go." Grasping the large referred to cultivating large SOEs that were strong and competitive, and eventually developing them into multinational companies. Letting the small go implied that the government would give up control of small and medium enterprises (SMEs). The government employed various methods to spin off SMEs, such as bankruptcy, merger and acquisition, leasing, and sale. The ultimate purpose of the strategy was to allow the state to retreat from competitive sectors by privatizing SMEs, and dominate a few strategic industries. The latter were industries that were suitable as natural monopolies, or companies with economies of scales realized through control of a limited number of large, central and local SOEs (Zheng and Chen 2007).

To achieve the objective of these reforms, the government recapitalized the targeted large enterprises by converting state loans to equities, authorizing state banks to write off bad loans, selectively listing firms in stock markets, and allowing the firms to form joint ventures with foreign investors. In addition, redundant workers were laid off, and all social welfare functions such as provision of housing, schools, hospitals, and pensions were removed from these enterprises.

The downsizing of SOEs was dramatic. It is estimated that about 30 million workers have been laid off since 1998 (Garnaut et al. 2005). The number of state-owned and state holding ${ }^{3}$ industrial enterprises dropped sharply from more than 64,000 in 1998 to about 21,000 in 2007 . The total number of employees shrank $54 \%$ to 17.4 million-corresponding to about $22 \%$ of the total labor force employed in all industrial enterprises, down from 60\% in 1998 (Table 1). Industrial SOEs as a whole became leaner in terms of number and work force, but stronger and more competitive. Measured by assets, the average size of industrial SOEs rose to CNY765 million, more than five times larger than in 1998; owners equity almost doubled to CNY6.6 trillion, indicating that the strategy of grasping the large and letting the small go was successful. Moreover, with fewer firms and employees, the aggregate profits of SOEs in 2007 grew to about 20 times the level of 1998, exceeding CNY1.0 trillion.

\section{Table 1: Selected Indicators of State-Owned and State Holding Industrial Enterprises}

\footnotetext{
${ }^{3}$ The former means wholly state owned; the latter means that the state controls more than $50 \%$ of enterprise shares.
} 


\begin{tabular}{|c|c|c|c|c|c|c|c|}
\hline & \multirow{2}{*}{$\begin{array}{l}\text { No. of } \\
\text { Firms }\end{array}$} & \multicolumn{2}{|c|}{ Employees } & \multirow{2}{*}{$\begin{array}{l}\text { Assets } \\
\text { Billion Yuan }\end{array}$} & \multirow{2}{*}{$\begin{array}{l}\text { Average } \\
\text { Size by } \\
\text { Assets } \\
\text { Million } \\
\text { Yuan }\end{array}$} & \multirow{2}{*}{$\begin{array}{l}\text { Profits } \\
\text { (billion } \\
\text { Yuan) }\end{array}$} & \multirow{2}{*}{$\begin{array}{l}\text { Owner's } \\
\text { Equity } \\
\text { (billion } \\
\text { Yuan) }\end{array}$} \\
\hline & & millions & $\begin{array}{l}\% \text { of } \\
\text { labor } \\
\text { force }\end{array}$ & & & & \\
\hline 1998 & 64,737 & 37.5 & 60.5 & $7,491.6$ & 115.7 & 52.5 & $2,675.9$ \\
\hline 2003 & 34,280 & 21.6 & 37.6 & $9,451.9$ & 275.7 & 383.6 & $3,828.1$ \\
\hline 2007 & 20,680 & 17.4 & 22.1 & $15,819.0$ & 764.9 & $1,079.5$ & $6,856.9$ \\
\hline
\end{tabular}

Source: China Statistics Yearbook and the author's calculations.

While the assets of SOEs continue to grow, a series of enterprise reforms loosened government control over enterprise investment and management. The government realized that it was imperative to have an agency to supervise and manage state assets. In 2003, the State-owned Asset Supervision and Administration Commission (SASAC) of the State Council was established. SASAC was mandated to consolidate functions previously scattered over various government agencies, and to regulate and supervise central SOEs. SASACs at the local level were established to supervise SOEs owned by local governments.

The strategy of grasping the large and letting the small go not only indicated that small and medium SOEs could be privatized, but also served as a rationale for retaining state control of strategic industries considered indispensable to the economy. Unlike other transitional economies, such as the Russian Federation, complete privatization of SOEs has never been pursued in the PRC. The president of SASAC, Li Rongrong, stated that the state had to maintain absolute control of defense, power generation and distribution, telecommunication, oil and petrochemical, coal, civil aviation, and shipping. State control of these industries could insure that state ownership remained a pillar of the PRC economy (Xinhua News 2006).

After years of effort, state monopoly of these industries has been achieved. Central enterprises produce $70 \%$ of both hydro and power electricity generators, and control $82 \%$ of the civil aviation market and $60 \%$ of high-value-added steel products. China Mobile has 457 million customers, about $65 \%$ of the national mobile phone market. China Petrol accounts for $57 \%$ of national crude oil output and $80 \%$ of natural gas production (Nanfang Weekly 2009). With government support and monopoly power, 118 central enterprises under the jurisdiction of the central government earned CNY696 billion in profits in 2008 , accounting for $80 \%$ of the profits of all non-financial SOEs. China Mobile's profit topped CNY146 billion, making it the most profitable telecom company in the world. With profits of CNY135 billion, China Petrol was the most 
profitable oil company in Asia. Table 2 lists the 10 most profitable central enterprises in 2008. The profitability of these enterprises was hardly affected by the global economic recession, unlike the profitability of their peers in Europe, Japan, and the US. Among the 10 central enterprises, only 3 experienced reduced profits. Each of these giant enterprises belongs to a sector with high entry barriers. It is likely that their strong financial performance was attributable more to their monopoly position and preferential treatment by the government than to the efforts and capabilities of their employees.

Table 2: Profits of Central SOES in 2007 and 2008 (CNY billion)

\begin{tabular}{|c|l|c|c|c|c|}
\hline \multirow{2}{*}{ Enterprises } & \multicolumn{2}{c|}{ Revenues } & \multicolumn{2}{c|}{ Profits } \\
\cline { 3 - 6 } & & 2007 & 2008 & 2007 & 2008 \\
\hline & Total 118 Central Enterprises & $10,028.2$ & $11,870.5$ & $1,005.6$ & 696.2 \\
\hline 1 & China Mobile Communication Corp. & 397.2 & 451.9 & 127.4 & 145.8 \\
\hline 2 & China National Petroleum Corp. & $1,000.7$ & $1,273.0$ & 192.0 & 134.8 \\
\hline 3 & China National Offshore Oil Corp. & 162.0 & 194.8 & 56.5 & 67.8 \\
\hline 4 & Shenhua Group Corp. Limited & 107.1 & 144.0 & 29.8 & 38.3 \\
\hline 5 & China Unicom & 197.7 & 188.1 & 16.7 & 31.0 \\
\hline 6 & China PetroChemical Corp. & $1,227.9$ & $1,462.4$ & 75.7 & 26.4 \\
\hline 7 & Baosteel Group & 227.7 & 246.8 & 35.7 & 23.8 \\
\hline 8 & China Ocean Shipping & 158.5 & 190.6 & 34.1 & 17.4 \\
\hline 9 & China Three Gorges Corp. & 16.8 & 21.3 & 12.7 & 11.4 \\
\hline 10 & China Coal Energy Company & 57.7 & 71.3 & 8.0 & 11.3 \\
\hline
\end{tabular}

Source: SASAC

\subsection{Public Funds and Reform of State-Owned Banks}

In addition to the reform of enterprises, reform of the banking system began at the end of the 1990s. As a result, the four large state banks advanced from the verge of bankruptcy to high profitability. Hit by the financial crisis, US banks have been struggling with survival. Banks in the PRC, on the other hand, have weathered the financial crisis much better than their counterparts in Europe and the US. Once almost-bankrupt, the four largest state-owned banks-Agriculture Bank of China $(A B C)$, Industrial and Commercial Bank of China (ICBC), Construction Bank of China (CBC), and Bank of China (BC)—joined the club of global 500 in 2008 (Fortune 2009)

These four large banks owe much of their success to the injection of public funds. They were bailed out by the government with tax money several times after writing off nonperforming loans (NPLs). In 1998, NPLs of these banks amounted CNY2,170 billion, accounting for $40 \%$ of their total outstanding loans (People's Bank of 
China 2002). The Ministry of Finance subsequently issued CNY270 billion in bonds to raise funds to increase the capital of the four banks. Later, CNY1,400 billion in NPLs from the four banks were transferred to four state-owned asset management companies, which were funded with CNY40 billion from the Ministry of Finance and CNY192 billion from the People's Bank of China (PBC) for the purchase of NPLs.

In 2003, PBC provided US $\$ 45$ billion to help CBC and BC write off their NPLs and prepare for listing in stock markets. The public fund injections raised the capital adequacy of both banks and reduced their NPL ratios significantly. ICBC and ABC also received US $\$ 15$ billion and CNY130 billion, respectively, from PBC. With a series of public fund injections and internal restructuring - such as laying off redundant workers, diversifying ownership, and strengthening corporate governance-profits of all four of the large banks improved dramatically. From 2004 to 2007, profits of ICBC grew to CNY82 billion from CNY30 billion, and the profits of BC jumped to CNY46 billion, more than double the level of 2004 (Figure 4). In 2008, ICBC emerged as the most profitable bank in the world with profits of US $\$ 16$ billion (Fortune 2009). Although a publicly listed bank, the government owns $70 \%$ of ICBC shares. ICBC, however, has yet to pay any dividends to the government.

Figure 4: Profitability of the Four Large State Banks of the PRC, 2004-2007 


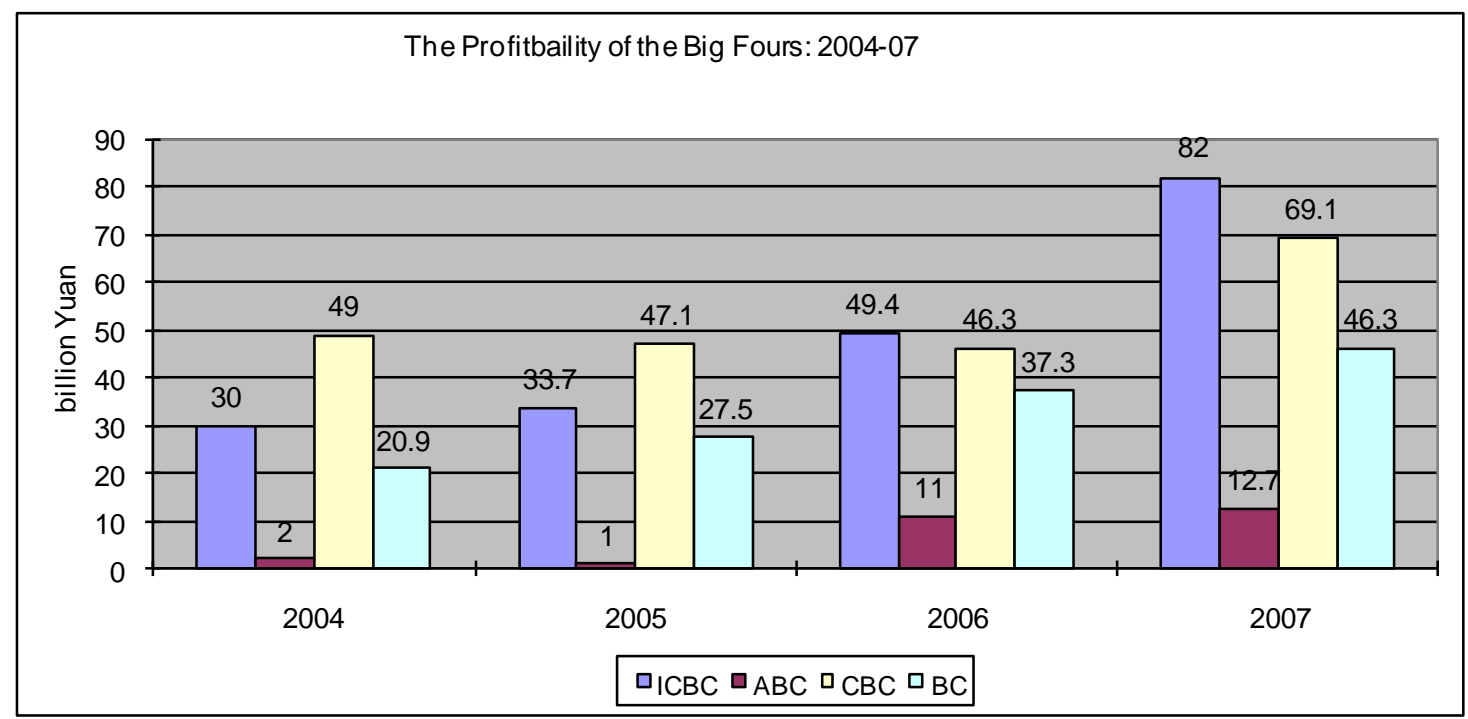

$\mathrm{ABC}=$ Agriculture Bank of China $\mathrm{BC}=$ Bank of China, $\mathrm{CBC}=$ Construction Bank of China, ICBC = Industrial and Commercial Bank of China

Source: China Financial Statistics.

Using tax money to bail out failed banks is not a unique practice. There are many predecessor cases. In the late 1990s, the Government of Japan used tax money to save private banks dragged down by NPLs accumulated after asset bubbles burst in 1989. Recently, the Government of the US injected more than US $\$ 800$ billion to rescue the largest US banks hit by the subprime loan crisis. In Japan and the US, however, injected public money is not free. All banks receiving public funds in these countries have a legal obligation to repay the money or face the risk of nationalization if they fail to survive. In the case of the PRC, however, it is not clear to the general public what obligations the four large banks have after receiving enormous amounts of tax money. It appears that these banks have no obligation to repay public funds. The ambiguity may be due to the assumption that these banks, despite being listed in stock markets, remain state-owned banks. If so, Chinese citizens, the real owners of these banks, are entitled to share their profits. No mechanism exists by which the general public, who shouldered all costs of bailing out these banks, could share in their profits.

\subsection{Who Benefits from the Profits of State-Owned Enterprises?}

Following tax reform in 1994, SOEs were exempted from paying dividends to the government and granted the right to retain all their post-tax profits. SOEs listed on stock markets do pay dividends to their wholly state-owned parent companies not listed on stock exchanges. The latter are holding companies, and retain all profits rather than pass them on to the government. Pressured by public criticism, the State Council began 
experiments in 2008 with collecting dividends from SOEs at rates of $10 \%$ and $5 \%$, depending on the industry. Firms in the defense industry or belonging to research institutes, and financial companies such as banks and insurance companies, were exempted. About CNY55 billion in dividends were collected in 2008. All dividends collected, however, were returned to central SOEs for various investment projects. No dividends were allocated for social welfare programs, which are severely underfunded.

Who benefits from the record profits of SOEs? Managers and employees of these firms are the major beneficiaries. One superficial justification for leaving huge amounts of profits to these SOEs is that they support the development of these firms. This practice, in fact, may not serve the best interests of shareholders. Theoretical studies show that, compared with bank loans and funds raised from issuing corporate bonds, retained profits are much cheaper (e.g, Gertler 1988; De Meza and Webb 1987). Investment with retained profits would be less efficient. Firms with excess cash tend to expand beyond optimal scales and invest in projects with low rates of return. Moreover, due to asymmetric information and weak supervision, it is highly likely that managers use retained profits for their own benefit at the cost of shareholders.

Current arrangements for allocation of SOE profits seriously undermine social equity. Only a small portion of employees working at SOEs enjoys high wages and handsome fringe benefits-notably workers in sectors with a state monopoly. Excluding compensation from stocks and options, the average income in 2007 of executive managers in state holding companies listed on stock markets was CNY340,000 (about US $\$ 50,000$ ) - more than 10 times higher than the average salary of workers (Su 2009). The recently uncovered "shadow stock" plan of China International Capital Corporation Limited (CICC) revealed how managers and employees of SOEs utilized state assets and guaranteed monopoly power to maximize their personal interests. CICC is controlled by China Investment Corporation, the sovereign fund of the PRC, with $43.4 \%$ of its shares. With the support of the government, CICC almost monopolizes the initial public offering (IPO) business of SOEs in overseas stock markets. CICC granted $20 \%$ of its shares to its managers and employees in the form of shadow stocks, substantially diluting the ownership of the state. In 2007, total employee compensation by CICC amounted US\$435 million, about half of company revenue (Wall Street Journal 2009).

Providing incentives-such as high salaries and stock options-to executive managers is argued to be an effective means of solving the principal agent problem in corporate governance and improving share values. In the PRC, however, SOE executive managers differ from private sector professional managers in a typical market economy. First, most SOE executive managers are appointed by the government, rather than selected through open competition in the labor market. Secondly, they are 
government officials. Their status and benefits as government officials remain even after they become SOE managers. Regardless of the performance of firms under their management, their status as government officials rarely changes. In other words, they are under no risk of pay cuts or being dismissed, as are professional managers working in private firms. Finally, the government has been using various measures to create a favorable environment for SOE growth, such as easy credit and deliberate accommodation of the monopoly power of SOEs. It is difficult to determine whether rising SOE profits are due to the contribution of managers or to monopoly power and government support (Su 2009). A few studies suggested that high manager compensation played a significant role in affecting the value of company shares and correlated with the performance of listed firms (e.g, Firth, Fung, and Rui 2007; Kato and Long 2005). These studies not only ignored the reverse causality-i.e., high profits leading high compensation-but also incorrectly assumed that SOE managers face the same risks as professional managers in a typical market economy.

A recent survey conducted by the Shanghai Human Resources and Social Security Bureau (2009) of aggregate labor compensation (including basic salary and all benefits) indicated that state ownership is highly correlated with the level of compensation. The Bureau surveyed 6,210 companies in 10 sectors in Shanghai. Within each sector, firms were classified according to ownership structure: state, collective, foreign, HK\&Taiwan\&Macau, ${ }^{4}$ and private. The results showed that banking and finance companies provided the highest compensation-on average CNY221,000 (US $\$ 32,500$ ) per employee or about five times higher than compensation in the hotel and restaurant sector, the sector with lowest compensation. Within the financial sector, state-owned financial enterprises paid CNY240,000, the highest compared with non-state financial companies. Yet, both return on assets and return on equity of state-owned banks were lower than such returns of foreign banks in the PRC. Using marginal labor productivity as a rule for determining labor compensation, the higher compensation offered by state-owned banks was not justifiable economically.

Higher compensation by state-owned financial firms compared to non-state financial firms is not a practice unique to the financial sector. In eight out of the ten sectors covered by the survey, average compensation by state-owned firms was highest. In the utility industry, annual compensation of SOEs averaged CNY138,000, about 4.5 times higher than in collectively owned firms, which offered the lowest worker compensation in the sector. In the financial sector, compensation by state-owned banks was CNY156,000 higher than the lowest compensation offered by collectively owned

\footnotetext{
${ }^{4}$ State: firms owned and controlled by the state; collective: firms owned collectively by individuals or different entities; HK\&Taiwan\&Macau: firms owned by investors from Hong Kong, China; Taipei,China; or Macau.
} 
banks (Figure 5). It is well known that both the utility and banking sectors are largely monopolized by SOEs.

Figure 5: Average Employee Compensation by Sector and Ownership in Shanghai, 2008

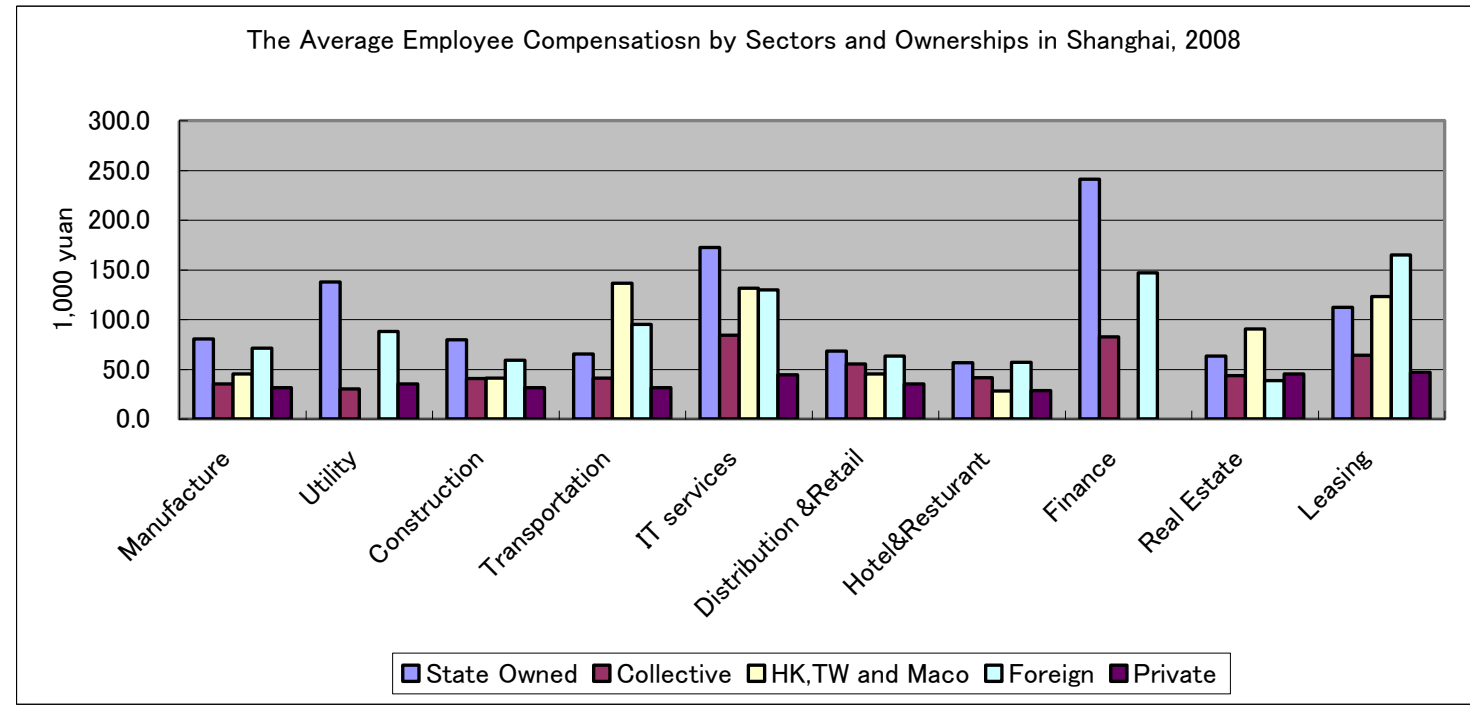

Source: Shanghai Human Resources and Social Security Bureau (2009)

It is not difficult to understand differences in compensation by sector. Industry-specific factors such as relative market competition, specific labor skills, average firm size, and technology affect worker compensation across sectors. Within a sector, on the other hand, labor mobility tends to equalize compensation across firms. The survey, however, suggested that compensation within the same sector varies substantially. In particular, SOEs paid more than other types of firms in most sectors. The significant correlations between state ownership and compensation imply that SOEs either enjoy monopolistic profits, or their employees benefit at the cost of shareholders and the general public due to weakened supervision of compensation decisions. No similar survey is available for the whole of the PRC. In that the development of the market economy in Shanghai is the most advanced compared with other parts of the country, the survey provides insightful information about the relationship between state ownership and workers' compensation in contemporary PRC.

\section{State Ownership and Interindustry Income Disparity}

\subsection{State-Owned Enterprises and Income Disparity}

Rising income disparity has emerged as a major social problem in the PRC. The country's GINI index rose to 0.46 in 2006 from 0.35 in 1990, a fundamental factor 
undermining consumption growth (Chen et al. 2010). Income disparity has been widening not only between rural and urban areas, but also across industries. Interindustry disparity, notably the disparity between industries monopolized by a handful SOEs and industries facing intensive competition, has recently attracted public attention. In 1998, the average annual salary in the highest paying sector was 1.6 times that in the lowest. By 2008, the ratio had jumped to 4.5. A recent study showed that interindustry income disparity contributed about $10 \%$ to income disparity in urban areas (Wan and Lu 2008). The survey in Shanghai examined in the previous section revealed indirectly that workers in sectors with relatively strong dominance of SOEs receive high income.

As a first step to test the hypothesis that state ownership contributed to the increase in interindustry income disparity, weighted coefficients of variation were used to measure inter-sector wage disparity. The coefficient of variation is a measure of dispersion magnitude, indicating how widely the average wage in each industry fluctuates around the mean wage of all industries. Higher values of the coefficient indicate larger disparity. Since industry size varies in terms of number of employees, employment in each industry is used as a weight for calculating the coefficient of variation. Specifically, the employment-weighted wage coefficient of variation is defined as

$$
C V=\frac{1}{\bar{W}} \sqrt{\sum_{i=1}^{m}\left(w_{i}-\bar{W}\right)^{2} \frac{l_{i}}{L}}
$$

where $l_{i}$ denotes the number of employees in industry $i, L$ is the total number of employees in all industries, $w_{i}$ is the average wage of industry $i, \bar{W}$ is the average wage of all industries as a whole, and $m$ is the number of industries. The coefficients from 2001 and 2007 were estimated and the results illustrated in Figure 6. In 2001 , the coefficient of variation was 0.18 . It gradually increased to 0.24 in 2007 , about $33 \%$ higher. It is true that wages usually differ across industries due to many sector-specific factors. The estimated coefficients of variation indicate not only that wages vary among sectors, but also that the variation increased over time. To what extent the increase was due to the concentration of state ownership is the interest of the empirical analysis that follows.

\section{Figure 6: Interindustry Wage Difference}




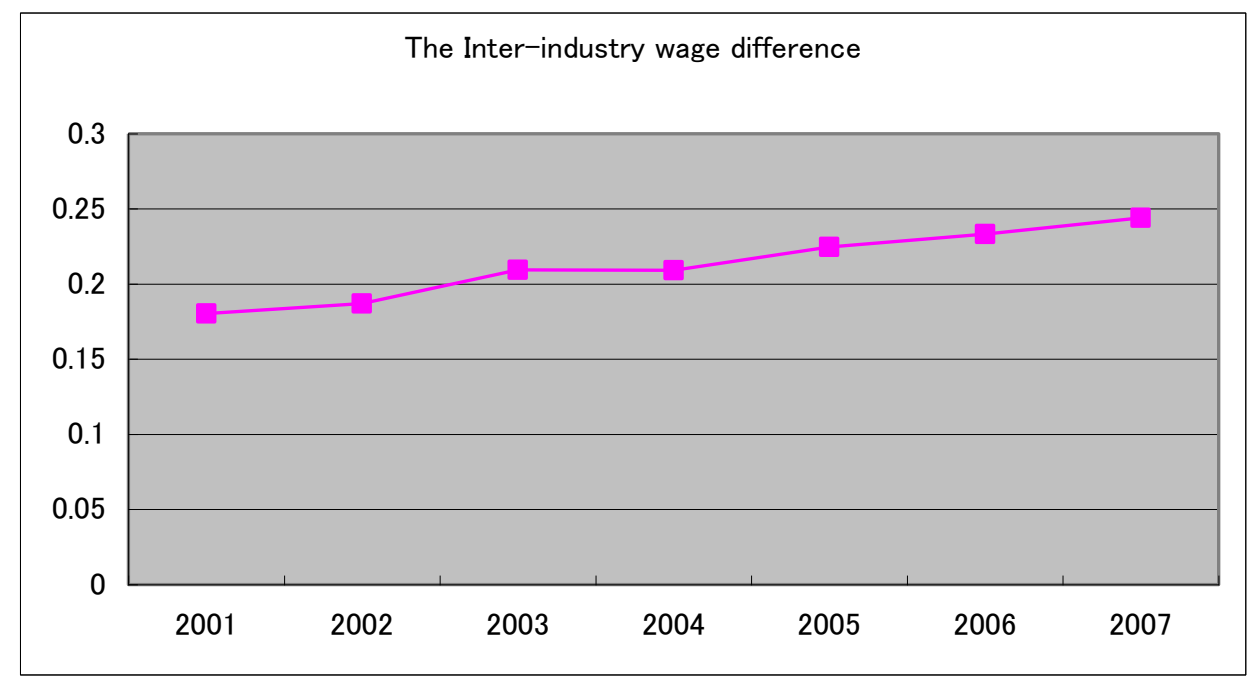

Source: Author's estimates.

Efficient wage theory provides an explanation for interindustry wage differences. To reduce turnover rates and stimulate employee productivity, some industries pay higher than the market equilibrium wage (Krueger and Summers 1988). Rent sharing theory ascribes wage differences to institutional structures of the labor market and wage negotiations between employers and labor unions. It emphasizes the influence of bargaining power between firm owners and labor organizations on wage determination. If workers are able to capture some share of the surplus of firms, this results in higher wages in industries with higher profits. Bell and Freeman (1991) concluded that rent sharing behaviors mainly accounted for rising US interindustry wage dispersion since the 1970 s.

These theories, however, explain very little of why interindustry wage disparity rises continuously in the PRC. There is no collective bargaining in Chinese firms. All labor unions are part of corporate management in the PRC. No firms face pressure to share their profits with their employees. Moreover, with about $9.4 \%$ unemployment in urban areas and an enormous number of rural migrants, Chinese workers are in effect paid much lower than their marginal productivity. Generally, efficiency theory does not apply to the PRC labor market, except for the markets for some highly specialized workers.

\subsection{Empirical Analysis}

The descriptive analysis of wage differences according to ownership structure and the monopoly power of SOEs in section 3 suggests that state ownership may be a significant factor in determining wage disparity across sectors. To test this hypothesis, 
wage determination based on a standard production function is used as a starting point.

It is assumed that the output of industry $i$ is determined by a production function with constant return to scale as shown below:

$$
Q_{i}=Q\left(K_{i}, h_{i} L_{i}\right)
$$

where $K$ denotes capital stock, $L$ labor input, and $h$ human capital embedded in one unit of labor. Thus, unit labor output in the industry can be written as

$$
q_{i}=Q\left(k_{i}, h_{i}\right)
$$

where $q_{i}=Q_{i} / L_{i}$ is the unit labor output and $k_{i}=K_{i} / L_{i}$ is capital stock per worker. The unit labor output $i$ is a standard measure for labor productivity, which determines labor wages. Equation 2 indicates that physical capital and human capital are two major variables determining labor productivity and wage. Following equation 2, a testable wage equation can be derived as

$$
\ln \left(w_{i}\right)=\alpha+\beta_{1} \ln \left(k_{i}\right)+\beta_{2} \ln \left(h_{i}\right)+e_{i}
$$

Equation 3 could be used to estimate wage level in each sector. However, the hypothesis concerns interindustry wage differences, not wage level. In other words, the fundamental purpose of the empirical test is to examine whether state ownership plays a significant role in interindustry wage differences. Using equation 3 , wage difference can be defined as

$$
\ln \left(\frac{w_{i}}{\bar{w}}\right)=\alpha+\beta_{1} \ln \left(\frac{k_{i}}{\bar{k}}\right)+\beta_{2} \ln \left(\frac{h_{i}}{\bar{h}}\right)+e_{i}
$$

where $\bar{w}$ is the average salary of all industries under consideration, $\bar{k}$ is the average capital per labor, and $\bar{h}$ is the average human capital. The dependent variable $\left(\frac{w_{i}}{\bar{w}}\right)$ actually measures the wage difference between industry $i$ and the average wage.

How to quantify state ownership in an individual industry is a challenging task. It is suggested that the share of sales of SOEs in an industry could be a close proxy to measure the concentration of SOEs in that industry. Data on SOE sales in individual industries, however, are not available. Instead, the share of SOE employment in an industry is used to measure the concentration of state ownership in that industry. The Organisation for Economic Co-operation and Development (2005) used the ratio of SOE employment in the economy to compare the involvement of the state in the PRC economy with state involvement in industrialized countries. Relative state control in an industry is defined as $\left(\frac{s_{i}}{\bar{s}}\right)$, where $s_{i}$ represents the share of employees working in SOEs in industry $i$, and $\bar{s}$ stands for the share of SOE employees in all industries. 
Including $\left(\frac{s_{i}}{\bar{s}}\right)$ into equation 4 as an additional independent variable gives rise to the following regression equation:

$$
\ln \left(\frac{w_{i}}{\bar{w}}\right)_{t}=\alpha+\beta_{1} \ln \left(\frac{k_{i}}{\bar{k}}\right)_{t}+\beta_{2} \ln \left(\frac{h_{i}}{\bar{h}}\right)_{t}+\beta_{3} \ln \left(\frac{s_{i}}{\bar{s}}\right)_{t}+e_{i t}
$$

Equation 5 is the final model estimated for testing the hypothesis that state ownership contributes to rising interindustry wage disparity. The model is estimated with panel data covering 12 industries in 2003-2007. A random effects model is selected for the estimation. The original data were collected from various issues of China Statistical Yearbook (National Bureau of Statistics Various years). Human capital $i$ is computed as the ratio of professionals to all employees in an industry; physical capital $i$ is calculated as fixed capital investment per employee.

Table 3: State Ownership and Interindustry Wage Differences

\begin{tabular}{|l|l|l|l|l|l|l|}
\hline & Constant & $\left(\frac{k_{i}}{\bar{k}}\right)$ & $\left(\frac{h_{i}}{\bar{h}}\right)$ & $\left(\frac{s_{i}}{\bar{s}}\right)$ & $\begin{array}{l}\text { Adj. } \\
R^{2}\end{array}$ & $\begin{array}{l}\text { Sample } \\
\text { Size }\end{array}$ \\
\hline Estimates & 0.072 & $0.041^{*}$ & $0.333^{\star \star *}$ & $0.103^{\star \star *}$ & 0.255 & 60 \\
& $(0.021)$ & $(0.022)$ & $(0.051)$ & $(0.020)$ & & \\
\hline
\end{tabular}

***: significant at $1 \%$; * significant at $10 \%$; the numbers in parentheses are standard errors.

Source: the author's estimates.

The estimates are reported in Table 3. The estimated coefficient of $\left(\frac{s_{i}}{\bar{s}}\right)$ is 0.103 and significant at $1 \%$, indicating that an industry with relatively more concentration of SOEs tends to pay higher salary. The estimated coefficient of $\left(\frac{k_{i}}{\bar{k}}\right)$ is 0.041 and significant at $10 \%$, and the estimated coefficient of $\left(\frac{h_{i}}{\bar{h}}\right)$ is 0.333 and significant at $1 \%$. The positive and significant coefficients of both physical capital and human capital differences are consistent with the theory that relatively higher physical capital and human capital lead to relatively higher salary.

Since both physical capital and human capital differences are included in the model as independent variables, the significance of $\left(\frac{s_{i}}{\bar{s}}\right)$, the relative SOE concentration, suggests that state ownership explains partly the residual wage 
difference, which cannot be attributed to either physical or human capital. The empirical result supports the hypothesis that SOEs pay higher salaries than non-SOEs, in general. It is difficult to find economic rationales to explain why state ownership could increase salary levels given that both physical capital and human capital are constant. Institutional reasons-e.g., state monopoly; weak corporate governance in SOEs, particularly of employee compensation decisions; and enormous amounts of retained profits-may contribute to the relative high compensation in SOEs.

\section{Concluding Remarks}

Income is the primary source of household consumption. Most studies of the high savings-low consumption myth in the PRC focused mainly on saving behaviors of Chinese households. This paper, however, argues that it is income not saving behavior that fundamentally constrains Chinese household consumption. Comparison of Chinese and Japanese households showed that the dynamic saving pattern of Chinese households is not so peculiar. Wage earnings remain a major source of household income in the PRC. Its share of national income declined steadily to $39 \%$ of GDP in the last decade, resulting in a reduced share of consumption in national income. Hence, measures aimed at improving the share of consumption in national income should start from raising the share of wage earnings in national income-a fundamentally more logical policy choice than reducing household saving rates.

Measured by the gross national saving rate, the PRC is unambiguously a country with exceptionally high savings. In order to reduce national savings with effective policies, it is imperative to understand who owns the savings. Decomposition of the structure of national savings reveals that corporate savings accounted for $23 \%$ of national income, and the growth of corporate savings contributed most to the significant increase in the national saving rate. How to reduce corporate savings rather than household savings should be the policy target for boosting aggregate consumption and lowering the gross national saving rate.

How to balance efficiency and equity has been a delicate and challenging issue for policy makers. In the last 3 decades, economic reform in the PRC has concentrated solely on efficiency and ignored social equity-a complete reversal of the utopian equity pursued under the centrally planned economy. Reform has greatly enhanced the bargaining power of capital and nurtured income distribution biased toward capital, which is in part responsible for surging corporate savings.

SOE monopolies in profitable and strategic industries, and dividend policy with regard to SOE profits, are both determined by government development strategies and have played an important role in widening the income distribution between labor and 
capital. While the number of employees in industrial SOEs dropped sharply to less than $22 \%$ of all industrial employees, retained profits by SOEs benefit only managers and employees in these firms. This is despite the fact that all Chinese citizens are the real owners of SOEs. Hence, the current arrangement has seriously undermined social justice and further amplified income disparity.

To stimulate domestic consumption, the bias of income distribution toward enterprises should be tackled. In particular, high priority should be given policy that tackles how the general public could benefit from the record profits of both financial and non-financial SOEs. Using part of SOE profits to fund social welfare services such as education, health care, and pensions, or even direct income transfers to lower-income households, would create tangible benefits to the general public and demonstrate their ownership of SOEs. Such measures would not only facilitate domestic consumption, but more importantly, alleviate social inequality. Efficiency has dominated the PRC's development agenda for last 30 years. Putting social equity ahead of efficiency can be justified now. 


\section{References}

$21^{\text {st }}$ Century Business Herald. 2009. Citizens May Benefits the profits of Central SOEs from three channels. 27 October.

Aziz, J., and Li Cui. 2007. Explaining China's Low Consumption: the Neglected Role of Household Saving. International Monetary Fund (IMF) Working Paper, WP/07/181. Washington, DC: IMF.

Bell, L., and R. Freeman. 1991. The causes of increasing inter-industry wage disparity in the United States. Industrial and Labor Relations Review 44(2): 275-287.

Cai, F., M. Wang, and Y. Qu. 2009. Industrial and Labor Relocations among Chinese Regions. Paper presented at the Asian Development Bank Institute conference, Labor Market in the People's Republic of China and its Adjustment to Global Financial Crisis. Tokyo. 18-19 June.

Chamon, M., and E. Prasad. 2008. Why are Saving Rates of Urban Households in China Rising? The Institute for the Study of Labor (IZA) Working Paper No. 3191. Bonn: IZA.

Chen et al. 2010. The Trend of Gini Coefficient of China. Brooks World Poverty Institute Working Paper 109. Manchester: University of Manchester.

De Meza, D., and D.C. Webb. 1987. Too Much Investment, a Problem of Asymmetric Information. Quarterly Journal of Economics (May): 281-292.

Feng, J., L. He, and H. Sato. 2009. Public Pension and Household Saving: Evidence from China. Bank of Finland's Institute for Economies in Transition (BOFIT) Discussion Paper No. 2. http://www.bof.fi/bofit_en/tutkimus/tutkimusjulkaisut/dp/2009/dp0209.htm

Firth, M., P. Fung, and O. Rui. 2007. How Ownership and Corporate Governance Influence Chief Executive Pay in China's Listed Firms. Journal of Business Research 60(7): 776-785.

Fortune. 2009. Fortune Global 500. 
http://money.cnn.com/magazines/fortune/global500/2009/industries/192/index $\underline{. \mathrm{html}}$

Garnaut et al. 2005. China's Ownership Transformation: Process, Outcomes, Prospects. Washington, DC: World Bank.

Gertler, M. 1988. Financial Structure and Aggregate Economic Activity: an Overview. Journal of Money, Credit and Banking 20 (August): 559-588.

Japanese Cabinet Office. 2005. Annual Report on the Japanese Economy and Public Finance 2003-04. Tokyo: Government of Japan.

Kato, T., and C. Long. 2005. Executive Compensation, Firm Performance, and Corporate Governance in China: Evidence from Firms Listed in the Shanghai and Shenzhen Stock Exchanges. The Institute for the Study of Labor (IZA) Discussion Paper No. 1767. Bonn: IZA.

Krueger, A., and L. Summers. 1988. Efficiency Wages and the Inter-Industry Wage Structure. Econometrica 56(2): 259-293.

Kuijs, L. 2005. Investment and Saving in China. World Bank Policy Research Working Paper 3633. Washington, DC: World Bank.

Lin, J., F. Cai, and Z. Li. 2003. The China Miracle: Development Strategy and Economic Reform. Hong Kong: Chinese University Press.

Lu, Feng, Guoqing Song, JieTang, Hongyan Zhao, and Liu Liu. 2008. Profitability of Chinese Firms, 1978-2006. China Economic Journal 1(1): 1-31.

Lu, M., and H. Gao. 2009. When Globalization Meets Urbanization: Labor Market Reform, Income Inequality and Economic Growth in China. Paper presented at the Asian Development Bank Institute conference, Labor Market in the People's Republic of China and its Adjustment to Global Financial Crisis. Tokyo. 18-19 June.

Meng, X. 2003. Unemployment, Consumption Smoothing, and Precautionary Saving in 
Urban China. Journal of Comparative Economics 31(3): 465-485.

Ministry of Finance, Government of the People's Republic of China. 2008. State-owned Enterprises with a record profit of 1.62 trillion Yuan. Beijing: Government of the People's Republic of China.

Modigliani, F., and S. Cao. 2004. The Chinese Saving Puzzle and the Life-Cycle Hypothesis. Journal of Economic Literature 42(1): 145-170.

Nanfang Weekly. 2009. The Big Changes of Central SOEs after Ten Years: the Origin and the Future (in Chinese). 20 August.

National Bureau of Statistics, Government of the People's Republic of China. Various years. China Statistical Yearbook. Beijing: China Statistics Press.

Organisation for Economic Co-operation and Development (OECD). 2005. Economic Survey of China 2005. Paris: OECD.

Peng, Z. 2009. Some Opinions on China's Consumption Statistics. http://www.stats.gov.cn/tiyi/tjggyi/t20091201 402604787.htm.

People's Bank of China (PBC). 2002. The Development Report of China's Financial Market 2002. Beijing: PBC.

Shanghai Human Resources and Social Security Bureau, Shanghai Municipal People's Government. 2009. Survey on Employee Compensation by Sectors (in Chinese). Shanghai: Shanghai Municipal People's Government.

Su, H. 2009. Some thoughts about how to regulate executives pay in State owned Enterprises. Institute of Labor and Wages, Chinese Ministry of Personnel. Beijing: Government of the People's Republic of China.

Tyers, R., and F. Lu. 2009. Competition Policy, Corporate Saving and China's Current Account Surplus. Working paper in Economics and Econometrics No. 496. Canberra: The Australian National University.

Wall Street Journal. 2009. The Secret of CICC Shadow Stocks. 20 November. 


\section{http://chinese.wsj.com/gb/20091120/ffe091249.asp}

Wan, Guanghua. 2007. Understanding Regional Poverty and Inequality Trends in China: Methodological Issues and Empirical. Findings, Review of Income and Wealth. 53(1): 25-34.

Wan, Guanghua, and Ming Lu. 2008. Inter-industry Disparity: An Important Factor Causing Income Disparity in Urban Areas. Department of Economics Working Paper. Shanghai: Fudan University.

Wiemer, C. 2009. Understanding China's High Saving. East Asian Institute Background Briefing No. 476. Singapore: National University of Singapore.

Xing, Y. 2009. The Global Economic Recession and Challenges to China's Export-led Growth Strategy. Paper presented at the Conference on Global Economic Crisis: Impact and Implications for Industrial Restructuring in Asia. Taipei,China. 19-20 August.

Xinhua News. 2006. SASAC: the State-owned Economy Should Maintain Absolute Control in Seven Sectors. 19 December.

Zheng, Y., and M. Chen. 2007. China's Recent State-Owned Enterprise Reform and its Social Consequences. China Policy Institute, Briefing Series Issue 23. Nottingham: University of Nottingham.

Zhou, X. C. 2009. Issues Related to the Global Financial Crisis. Speech delivered at the Global Think-Tank Summit. Beijing. July. 